\title{
PENGARUH KETEBALAN IRISAN CHIPS SINGKONG DAN LAMA FERMENTASI TERHADAP SIFAT FISIKO KIMIA TEPUNG MOCAF (MODIFIED CASSAVA FLOUR)
}

\author{
Sohib Assalam ${ }^{1)}$, Novian Wely Asmoro ${ }^{1)}$, A. Intan Niken Tari ${ }^{1)}$, dan Sri Hartati ${ }^{1)}$ \\ 1)Fakultas Pertanian, Jurusan Teknologi Hasil Pertanian, Universitas Veteran Bangun Nusantara, \\ Jl. Letjend S. Humardani No 1 Jombor Sukoharjo, Telp (0271) 593156, \\ Korespondensi email: novianwelyasmoro@gmail.com
}

\begin{abstract}
Abstrak
Modified cassava flour atau mocaf merupakan tepung singkong yang mengalami modifikasi menggunakan prinsip fermentasi bakteri asam laktat. Salah satu faktor yang perlu diamati yaitu proses fermentasi yang akan berpengaruh terhadap kualitas tepung mocaf yang dihasilkan. Penelitian ini bertujuan untuk mengetahui pengaruh ketebalan irisan chip singkong dan lama fermentasi dalam proses pembuatan tepung mocaf terhadap kualitas fisiko kimia tepung mocaf. Metode penelitian menggunakan RAL Faktorial dengan 2 variabel perlakuan yaitu ketebalan irisan chips singkong $(0,5 \mathrm{~cm}, 1 \mathrm{~cm}, 1,5 \mathrm{~cm})$ dan lama fermentasi $(24$ jam dan 48 jam), sehingga dihasilkan 6 kombinasi perlakuan dan diulang sebanyak 3 kali ulangan, sehingga terdapat 18 unit percobaan. Data yang diperoleh diolah dengan Analysis of Variance (ANOVA) menggunakan software SPSS 22. Jika hasil uji ANOVA menyatakan bahwa sampel yang diujikan berbeda nyata, maka dilakukan uji lanjut DMRT (Duncan Multiple Range Test) pada taraf kepercayaan 0.05 . Rendemen tepung mocaf yang diperoleh berkisar antara 30,47\% - 32,98\% dengan kadar air terendah $10,31 \%$. Rata-rata nilai swelling power tepung mocaf sebesar $12,24 \mathrm{~g} / \mathrm{g}$ dan Rata-rata indeks kelarutan dalam air sebesar $5,29 \%$.
\end{abstract}

Kata kunci : Chips, Ketebalan, Lama Fermentasi, Tepung Mocaf

\begin{abstract}
Modified cassava flour or mocaf is cassava flour which has been modified using the principle of lactic acid bacteria fermentation. One factor that needs to be observed is the fermentation process which will affect the quality of the mocaf flour produced. This study aims to determine the effect of cassava chip slice thickness and fermentation time in the process of making mocaf flour on physico-chemical quality of mocaf flour. The research method used Factorial RAL with 2 treatment variables, namely the thickness of cassava chips slices $(0.5 \mathrm{~cm}, 1 \mathrm{~cm}, 1.5 \mathrm{~cm})$ and fermentation time (24 hours and 48 hours), resulting in 6 treatment combinations and repeated 3 replications, so there are 18 experimental units. The data obtained was processed by Analysis of Variance (ANOVA) using SPSS 22 software. If the ANOVA test results stated that the samples tested were significantly different, then DMRT (Duncan Multiple Range Test) was carried out at the 0.05 confidence level. The yield of mocaf flour obtained ranged from $30.47 \%-32.98 \%$ with the lowest moisture content of $10.31 \%$. The average swelling power of mocaf flour is $12.24 \mathrm{~g} / \mathrm{g}$ and the average water solubility index is $5.29 \%$.
\end{abstract}

Keywords: Chips, Thickness, Fermentation Length, Mocaf Flour 


\section{PENDAHULUAN}

Singkong (Manihot esculenta)atau ubi kayu banyak ditanam oleh masyarakat Indonesia yang bermanfaat sebagai salah satu sumber pangan. singkong memiliki karbohidrat yang tinggi, menurut dan dapat digunakan sebagai sumber karbohidrat alternatif selain beras dan terigu. Produksi ubi kayu dari tahun ke tahun mengalami penurunan, menurut data BPS penurunan produksi singkong dari tahun 2012 sebesar 24.177.372 (dalam ton) menjadi 23.436.384 (dalam ton) pada tahun 2014, yang berarti terjadi penurunan sebesar $3.06 \%$ (BPS, 2016). Penurunan ini menandakan bahwa semakin banyak impor tepung singkong yang dilakukan sehingga perlu dicari cara untuk mengolah singkong tersebut.

Pengolahan singkong biasanya sering dibuat menjadi cemilan, seperti : keripik, opak atau cemilan basah yang berbahan baku singkong hanya saja cemilan seperti ini memiliki waktu simpan yang tidak tahan lama. Pengolahan singkong dengan hasil produk yang cukup tahan lama adalah pembuatan tepung ubi kayu seperti pembuatan gaplek, pembuatan tapioka dan pembuatan mocaf (Pato et al., 2011; Nusa, Suarti and Alfiah, 2012; Asmoro, Hartati and Handayani, 2017; Kamsina, Nurmiati and Periadnadi, 2017).

Umumnya produk ini termasuk kategori produk antara yaitu produk yang dapat diolah menjadi produk lain atau produk yang memerlukan bahan lain dalam proses pengolahannya (Ginting, 2009). Teknologi pengolahan mocaf masih dilakukan dalam skala kecil dan rumahan. Beberapa industri mocaf bahkan masih dilakukan oleh para petani dengan cara sederhana.

Mocaf atau modified cassava flour merupakan tepung singkong yang mengalami modifikasi yang diproses menggunakan prinsip fermentasi. Tepung mocaf yang dihasilkan memiliki karakteristik yang lebih baik, aromanya yang normal dan warna yang lebih bagus. Beberapa sifat berupa naiknya viskositas, kemampuan gelasi, daya rehidrasi, dan kemudahan melarut juga akan semakin baik (Frediansyah, A; Kurniadi, M; Nurhikmat, A; Susanto, 2012).

Pengolahan tepung mocaf bisa menggunakan starter berupa mikroorganisme baik bakteri, kapang dan khamir. Kemampuan mikroorganisme dalam memfermentasikan mocaf dengan memecah karbohidrat menjadi komponen yang lebih sederhana yaitu asam laktat, beberapa bakteri juga menghasilkan enzim amilase yang dapat memecah komponen dari karbohidrat yaitu amilosa (Petrova et al., 2013). Pembuatan tepung mocaf biasanya menggunakan starter komersial tetapi dapat juga menggunakan ragi roti, ragi tempe dan bakteri asam laktat (Kurniati et al., 2012). Penelitian Gunawan et al. (2015) menyatakan bahwa penggunaan beberapa mikroorganisme seperti bakteri Lactobacillus plantarum, kapang Rhizopus oryzae dan khamir Saccharomyces cereviseae dalam pembuatan mocaf menghasilkan produk mocaf yang cukup baik, baik dari segi karakteristik tepung berupa warna bau dan rasa serta dari penurunan kadar sianida di singkong Beberapa sentra pengolahan singkong menjadi mocaf bahkan sudah menggunakan bakteri asam laktat berupa Lactobacillus plantarum dalam proses fermentasinya (Frediansyah et al., 2012).

Selain penggunaan mikroorganisme dalam pembuatan tepung mocaf, diduga ketebalan irisan chips singkong dan lama 
Agrisaintifika

Assalam, et al 2019

fermentasi juga berpengaruh terhadap kualitas sifat fisiko kimia tepung mocaf yang dihasilkan. Untuk saat ini banyak penelitian tentang tepung mocaf yang menggunakan pengaruh lama fermentasi, pada umumnya dapat memberi pengaruh nyata terhadap sifat fisiko kimia tepung mocaf. Tetapi belum diketahui pengaruh kombinasi ketebalan irisan chips singkong dan lama fermentasi terhadap kualitas fisiko kimia tepung mocaf, oleh karena itu penelitian ini dilakukan untuk mengetahui pengaruh ketebalan irisan chips singkong dan lama fermentasi terhadap sifat fisiko kimia tepung mocaf.

\section{BAHAN DAN METODE}

Penelitian ini dilakukan bulan Oktober sampai dengan Desember 2018. Tempat penelitian di Laboratorium Fakultas Pertanian Universitas Veteran Bangun Nusantara Sukoharjo.

\section{Bahan}

Singkong jenis Kaporo yang didapat dari pasar tradisional di Kecamatan Simo Kabupaten Boyolali Jawatengah, bahan utama lain yang digunakan adalah starter dengan merk starmof produksi LIPI Yogyakarta yang didalamnya mengandung bakteri asam laktat.

\section{Metode}

Penelitian ini dirancang untuk dapat mengetahui karakter fisiko kimia tepung mocaf yang terdiri dari rendemen, kadar air, swelling power dan indeks kelarutan dalam air. Pembuatan irisan chip singkong terdapat 3 ukuran yang berbeda yaitu 0,5 $\mathrm{cm}, 1 \mathrm{~cm}$ dan $1,5 \mathrm{~cm}$. Lama fermentasi terdapat 2 variabel yaitu 24 jam dan 48 jam. Penelitian percobaan menggunakan RAL dengan 2 faktor yaitu ketebelan irisan chips singkong $(0,5 \mathrm{~cm}, 1 \mathrm{~cm}, 1,5 \mathrm{~cm})$ dan lama fermentasi (24 jam 48 jam) masing-masing perlakuan diulang sebanyak 3 kali, sehingga terdapat $3 \times 2 \times 3=18$ satuan percobaan. Analisis sampel meliputi kenampakan/visual, rendemen, kadar air, swelling power dan indeks kelarutan dalam air. Data yang diperoleh akan diolah secara statistik dengan uji Analysis of Variance (ANOVA) menggunakan SPSS 17. Jika hasil uji ANOVA menyatakan bahwa sampel yang diujikan berbeda maka akan dilakukan uji lanjut DMRT nyata pada taraf kepercayaan $95 \%$.

\section{HASIL DAN PEMBAHASAN}

\section{Penampakan Tepung Mocaf}

Tepung mocaf juga diuji berdasarkan sifat organoleptiknya. Rata-rata hasil pengujian sifat organoleptik mocaf yang bervariasi berdasarkan ketebalan irisan chip dan lama fermentasi dapat dilihat pada Tabel 1. 
Assalam, et al 2019

Tabel 1.Visual tepung mocaf hasil penelitian

\begin{tabular}{ccc}
\hline Mocaf & Warna & Aroma \\
\hline A & ++++ & ++++ \\
B & +++ & +++ \\
C & ++++ & ++++ \\
D & +++ & +++ \\
E & ++++ & ++++ \\
F & ++ & ++ \\
\hline
\end{tabular}

\section{Keterangan: \\ Warna ++++ Putih \\ $++\quad$ Cukup Putih \\ $++\quad$ Coklat \\ Aroma $++++\quad$ Tidak beraroma \\ $+++\quad$ Sedikit beraroma asam \\ $++\quad$ Beraroma asam}

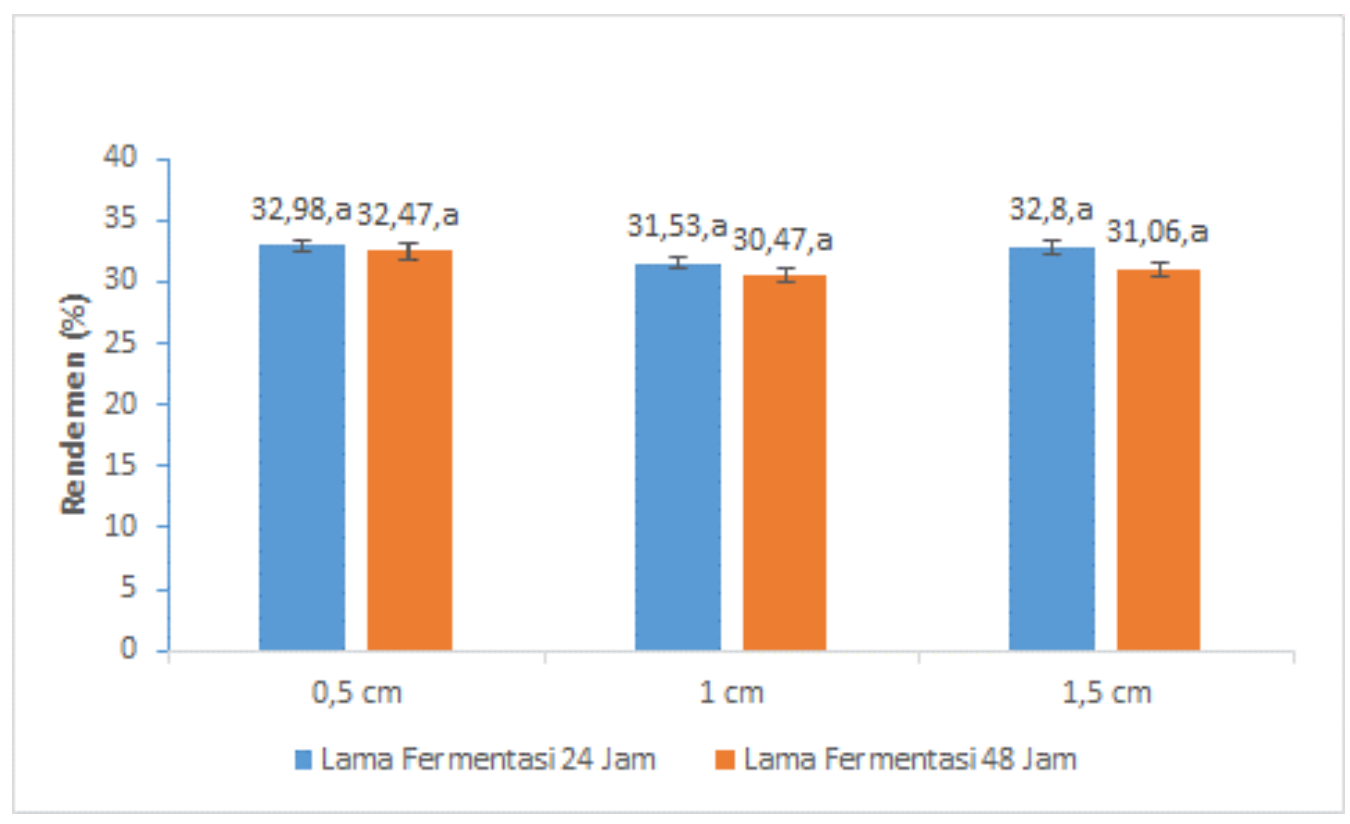

Gambar 1. Grafik Rendemen Tepung Mocaf 
Agrisaintifika

Jurnal Ilmu-Ilmu Pertanian

Vol. 3, No. 1, 2019

Assalam, et al 2019

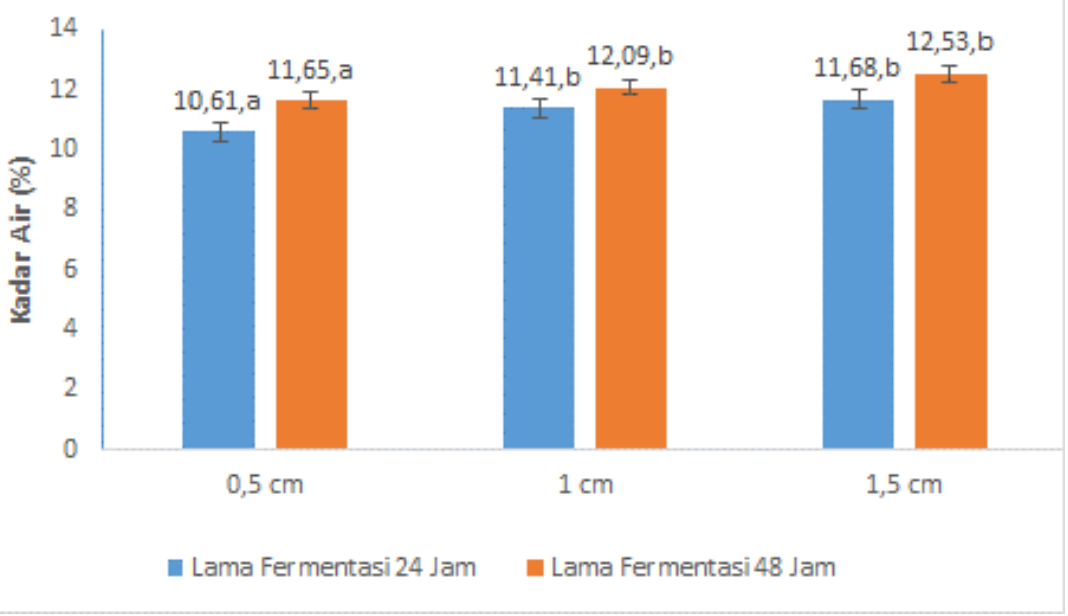

Gambar 2. Grafik Kadar Air Tepung Mocaf

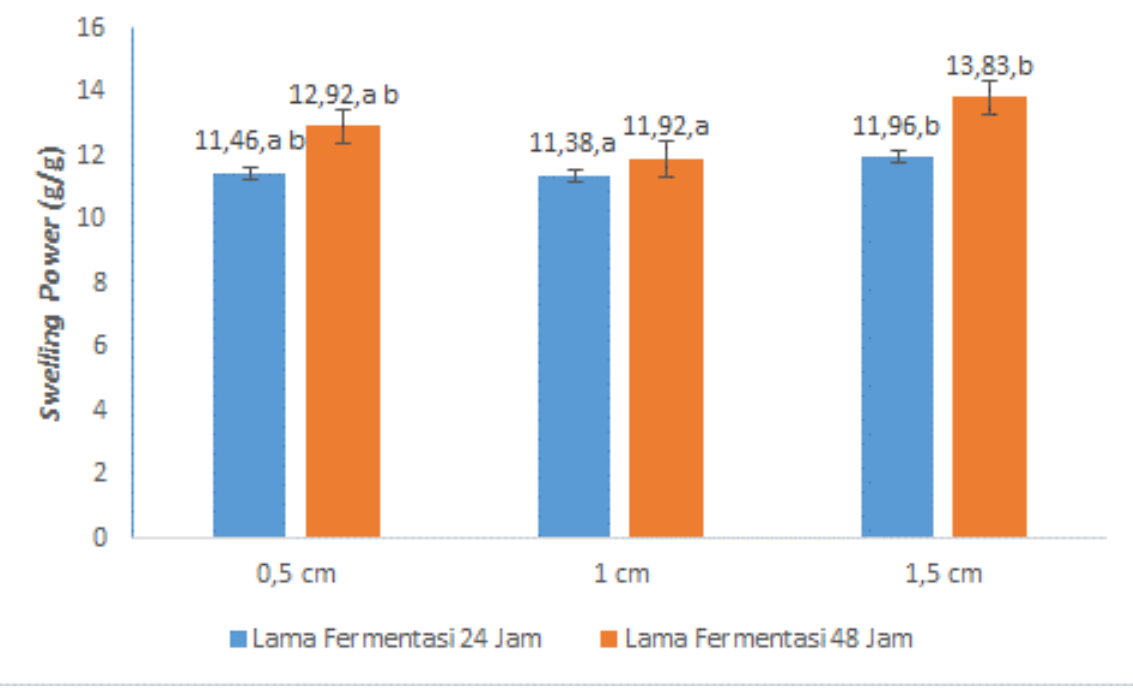

Gambar 3. Grafik swelling Power Tepung Mocaf 
Agrisaintifika

Jurnal Ilmu-Ilmu Pertanian

Vol. 3, No. 1, 2019

Assalam, et al 2019

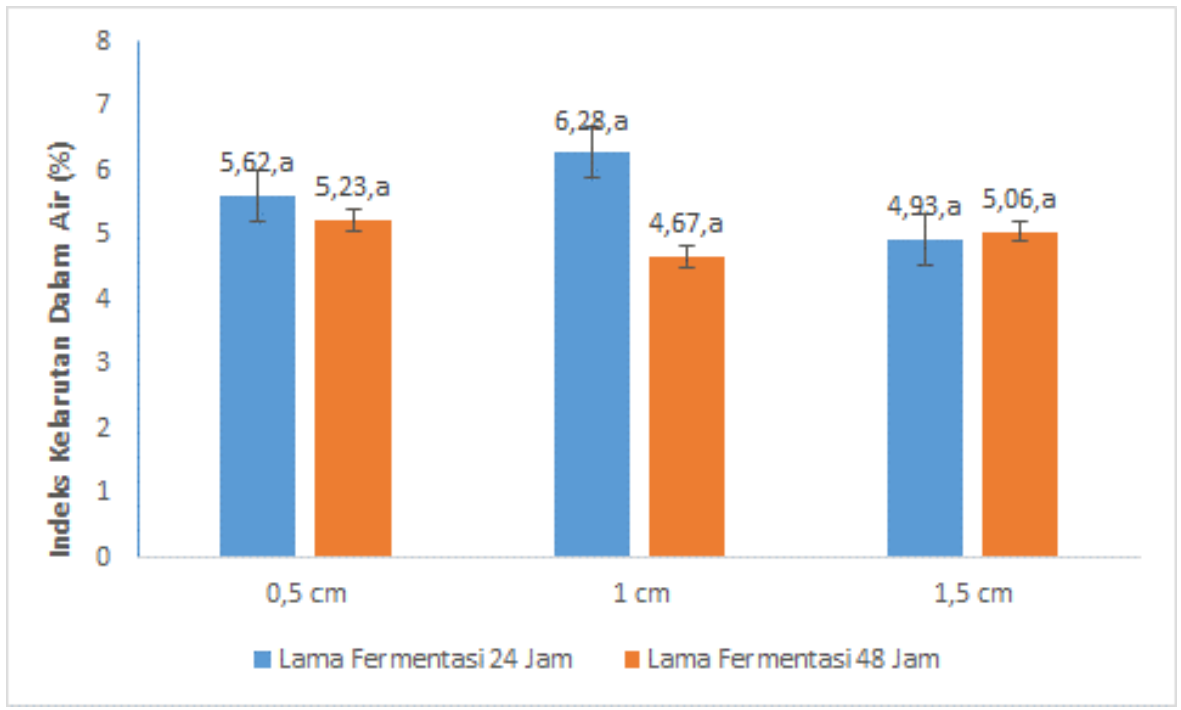

Gambar 4. Grafik Indeks Kelarutan dalam Air Tepung Mocaf

\subsection{Rendemen}

Hasil analisis statistik terlihat bahwa ketebalan irisan dan lama fermentasi tidak berpengaruh nyata $(P>0,05)$ terhadap rendemen tepung mocaf. Pada Gambar 1 memperlihatkan bahwa rendemen tepung mocaf maksimum yang diperoleh sebesar $32,98 \%$ yang dihasilkan dari $0,5 \mathrm{~cm}$ tebal chips singkong, difermentasi selama 24 jam dan dikeringkan selama 72 jam. Rendemen tepung mocaf minimum yang diperoleh sebesar $30,47 \%$ yang dihasilkan dari $1 \mathrm{~cm}$ tebal chips singkong, difermentasi selama 48 jam dan dikeringkan selama 72 jam. Rata rata rendemen sebesar $31,88 \%$. Setelah dianalisis ANOVA dan uji lanjutan DMRT tidak berbeda nyata $(P>0,05)$ Penelitian yang dilakukan Seveline pada tahun 2018 rendemen tepung mocaf berkisar antara 26,59\%-37,23\% sedangkan penelitian yang dilakukan Nusa (2012) rendemen tepung mocaf berkisar antara $30,85 \%-36,23 \%$.

Jumlah rendemen dipengaruhi oleh bentuk fisik singkong secara morfologis karena pada pembuatan tepung seluruh komponen yang terkandung di dalam bahan pangan dipertahankan keberadaanya kecuali air.

\subsection{Analisa kadar air}

Hasil analisis statistik pengaruh ketebalan irisan dan lama perendaman terhadap kadar air tepung mocaf, terlihat bahwa ketebalan irisan berpengaruh nyata $(\mathrm{P}<0,05)$ terhadap kadar air tepung mocaf.

Pada Gambar 2 memperlihatkan bahwa kadar air tepung mocaf maksimum yang diperoleh sebesar $12,53 \%$ yang dihasilkan dari $1,5 \mathrm{~cm}$ tebal chips singkong, difermentasi selama 48 jam dan dikeringkan selama 72 jam. Kadar air tepung mocaf minimum yang diperoleh sebesar 10,61\% yang dihasilkan dari $0,5 \mathrm{~cm}$ tebal chips singkong, difermentasi selama 24 jam dan dikeringkan selama 72 jam. Rata rata kadar air sebesar 11,66 \%. Penelitian yang dilakukan Seveline (2018) kadar air tepung mocaf berkisar antara 6,11\%-8,89\% sedangkan penelitian yang dilakukan Nusa (2012) kadar air tepung mocaf berkisar antara 6,41\%-6,14\%. Kadar air akan semakin meningkat sebanding dengan lama fermentasi dalam pembuatan mocaf. Kadar air yang dihasilkan juga dipengaruhi oleh proses pengeringan yang dilakukan setelah proses fermentasi. Semakin lama proses 
Agrisaintifika

Jurnal Ilmu-Ilmu Pertanian

Vol. 3, No. 1, 2019

Assalam, et al 2019

pengeringan maka kadar air juga akan semakin rendah tetapi dampak yang akan dihasilkan adalah pencoklatan pada bahan. Kualitas tepung sangat dipengaruhi oleh kadar air, kadar air yang terlalutinggi akan menyebabkan kerusakan pada bahan yaitu menjadi berjamur, apekdan berbau tengik atau bau-bau yang menyimpang dari bau normal bahan,bahkan dapat mempengaruhi umur simpan bahan menjadi lebih singkat karenamengalami kerusakan.

Pada SNI tepung mocaf kadar air maksimum adalah 13\%, hasil aplikasi starter pada skala laboratorium adalah berkisar antara $11,61 \%$, sehingga semua hasil penelitian terhadap kadar air masuk dalam kategori syarat mutu tepung mocaf yang sudah ditentukan SNI. Kadar air merupakan salah satu titik kritis pada tepung mocaf karena bila kadar air melebihi $13 \%$ dapat mempersingkat umur simpan tepung mocaf tersebut, karena merupakam kondisi ideal pada mikrobia.

\subsection{Swelling Power}

Swelling power tepung menunjukkan kemampuan pati berinteraksi dengan molekul air. Hasil analisis statistik pengaruh ketebalan irisan dan lama perendaman terhadap swelling power tepung mocaf, terlihat bahwa ketebalan irisan berpengaruh nyata $(P<0,05)$ terhadap swelling power tepung mocaf. Swelling power tepung mocaf maksimum yang diperoleh sebesar $13,83 \mathrm{~g} / \mathrm{g}$ yang dihasilkan dari $1,5 \mathrm{~cm}$ tebal chips singkong, difermentasi selama 48 jam dan dikeringkan selama 72 jam. Swelling power tepung mocaf minimum yang diperoleh sebesar11,38 g/g yang dihasilkan dari $1 \mathrm{~cm}$ tebal chips singkong, difermentasi selama 24 jam dan dikeringkan selama 72 jam. Rata rata swelling power sebesar $12,24 \mathrm{~g} / \mathrm{g}$. Penelitian yang dilakukan Wikansastri Hersoelistyorini (2015) swelling power tepung mocaf berkisar antara $13,72 \mathrm{~g} / \mathrm{g}-12,19 \mathrm{~g} / \mathrm{g}$ sedangkan penelitian yang dilakukan Nurud Diniyah (2018) swelling power tepung mocaf berkisar antara $4,15 \mathrm{~g} / \mathrm{g}-7,45 \mathrm{~g} / \mathrm{g}$.

Swelling power merupakankemampuan pati untuk mengembang. Selain itu, pada perlakuan lama fermentasi 24 jam dengan berbagai ketebalan irisan chips, nilai swelling powermocaf mengalami fluktuasidemikian pula pada lama fermentasi 48 jam.Penurunan nilai swelling power dapat disebabkan oleh perubahan bentuk dari amorf amilosa kedalam bentuk heliks, bentuk ini akan meningkatkan interaksi antara rantai amilosa amorf dan akan terjadi perubahan pada interaksi antara perubahan pada interaksi matriks amorf.

Peningkatan swelling power akibat peningkatan suhu pemanasan disebabkan karena kadar amilosa semakin rendah atau amilopektin dalam pati lebih tinggi. Kenaikkan suhu pemanasan suspensi pati menyebabkan proses gelatinisasi pati berjalan optimal yaitu fraksi amilosa meluruh keluar dari granula pati akibat pecahnya granula pati sehingga akan menurunkan kadar amilosa. Adanya pemanasan menyebabkan granula pati cepat mengembang dan ikatan intermolekuler hidrogen terlepas dan air akan berikatan dengan molekul pati.

\subsection{Indeks Kelarutan Dalam Air}

Hasil analisis statistik pengaruh ketebalan irisan dan lama perendaman terhadap indeks kelarutan dalam air tepung mocaf, terlihat bahwa ketebalan irisan tidak berpengaruh nyata $(P>0,05)$ terhadap indeks kelarutan dalam air tepung mocaf. Hasil analisis lanjutan berupa DMRT dapat dilihat pada Gambar 4, indeks kelarutan dalam air tepung mocaf maksimum yang diperoleh sebesar $6,28 \%$ yang dihasilkan dari $1 \mathrm{~cm}$ tebal chips singkong, difermentasi selama 24 jam dan dikeringkan selama 72 jam. Indeks kelarutan dalam air tepung mocaf minimumyang diperoleh sebesar $4,67 \%$ yang dihasilkan dari $1 \mathrm{~cm}$ tebal chips singkong, difermentasi selama 48 jam dan 
dikeringkan selama 72 jam. Rata rata indeks kelarutan dalam air sebesar 5,29\%.

Ditinjau berdasarkan tren data yang dihasilkan, nilai kelarutan tepung mocaf cenderung berflutuasi terhadap lama waktu fermentasi. Liberasi sel yang terjadi selama fermentasi akan memotong ikatan pada pati sehingga struktur nyamenjadi lebih sederhana dan sebagian juga berubah menjadi struktur dasarnya yaitu glukosa sehingga sifatnya menjadi larut air. Selain itu, modifkasi meningkatkan kelarutan pati. Adanya perbedaan kelarutan dan daya kembang menunjukkan perbedaan struktur dan kelarutan pati dan juga dapat dihubungkan dengan perbedaan panjang rantai/ distribusi pada pati.

Peningkatan kelarutan tepung diduga karena tepung telah dihidrolisas oleh asam laktat yang dihasilkan BAL yaitu Lactobacillus plantarum pada starter. sehingga mengakibatkan ukuran molekul pati yang lebih kecil, adanya ukuran molekul yang lebih kecil tersebut maka mudah untuk larut dalam air, semakin rendah panjang polimer rantai pati maka semakin tinggi kelarutannya. Molekul amilosa mudah terpecah dibandingkan dengan molekul amilopektin sehingga saat hidrolisa asam berlangsung akan menurunkan gugus amilosa.

Semakin mudahnya air yang masuk maka kecenderungan untuk membentuk hidrogen inilah yang menahan air untuk keluar dari granula pati sehingga pati tersebut dapat larut. (Novita Sari Dewi et al, 2012), namun teori ini belum berlaku pada penelitian pengaruh ketebalan irisan chips singkong 0,5-1,5 cm. Hal ini dimungkinkan karena fermentassi aerobik menyebabkan terjadinya perubahan karakteristik terutama berupa naiknya viskositas (daya rekat), kemampuan gelatinasi, daya rehidrasi, dan solubility (kemampuan melarut). Keberadaan mikroba pada fermentasi mocaf, baik secara spontan ataupun yang ditambahkan sebagai starter akan menghasilkan enzim pektinolitik dan sellulolitik yang dapat menghancurkan dinding sel ubi kayu sehingga terjadi liberasi granula pati Proses pembebasan granula pati akan menyebabkan perubahan karakteristik dari tepung yang dihasilkan berupa naiknya viskositas, kemampuan gelasi, daya rehidrasi, dan kemudahan melarut (Tandrianto, Mintoko and Gunawan, 2014; Kamsina, Nurmiati and Periadnadi, 2017)

\section{KESIMPULAN}

Perlakuan ketebalan irisan chips singkong $(0,5 \mathrm{~cm}, 1 \mathrm{~cm}, 1,5 \mathrm{~cm})$ berpengaruh nyata $(P<0,05)$ terhadap kadar air dan swelling power tepung mocaf, namun ketebalan irisan chips singkong tidak berpengaruh nyata $(P>0,05)$ terhadap indeks kelarutan dalam air tepung mocaf. Lama fermentasi 24 jam dan 48 jam berpengaruh nyata $(P<0,05)$ terhadap kadar air dan swelling power tepung mocaf, namun lama fermentasi 24 jam tidak berpengaruh nyata $P(>0,05)$ terhadap indeks kelarutan dalam air tepung mocaf. Tidak terdapat interaksi antara perlakuan ketebalan irisan chips singkong dan lama fermentasi.

\section{UCAPAN TERIMAKASIH}

Terimakasih diucapkan kepada LPPM Universitas Veteran Bangun Nusantara Sukoharjo dan DRPM Kemenristek Dikti yang telah memberikan dukungan dana dalam kegiatan pengabdian masyarakat melalui skema Program Kemitraan Masyarakat (PKM) pendanaan tahun 2018.

\section{DAFTAR PUSTAKA}

Asmoro, N. W., Hartati, S. and Handayani, B. (2017) 'Karakteristik Fisik dan Organoleptik Produk Mocatilla Chips dari Tepung Mocaf dan 
Agrisaintifika

Jurnal Ilmu-Ilmu Pertanian

Vol. 3, No. 1, 2019

Assalam, et al 2019

Jagung', Jurnal IImu Pangan dan

Hasil Pertanian, 1(1), pp. 63-70.

Dewi, dan Andri Cahyo Kumoro. 2015. Sifat Fisikokimia Dan Organoleptik Tepung Mocaf (Modified Cassava Flour) Dengan Fermentasi Menggunakan Ekstrak Kubis. The 2nd University Research Coloquium.

Frediansyah, A; Kurniadi, M; Nurhikmat, A; Susanto, A. (2012) 'Improving quality of mocaf (modified cassava flour) by bioprocess using Lactobacillus plantarum and its utility for foodstuff', in International Seminar on Enhanching Grasroot Innovation Competitiveness for Poverty Alleviation (EGICPA), pp. 140-145. Available at: http://bpptk.lipi.go.id/gri/?page_id= 289.

Kamsina, K., Nurmiati, N. and Periadnadi, P. (2017) 'Aplikasi Isolat Bakteri Indigenous Ubi Kayu Karet (Manihot Glaziovii) Pada Fermentasi Pembuatan Mocaf', Jurnal Litbang Industri, 7(2), pp. 111-121.

Novita Sari Dewi, Nur Her Riyadi Parnanto, Achmad Ridwan A. 2012. Karakteristik Sifat Fisikokimia Tepung Bengkuang (Pachyrhizus Erosus) Dimodifikasi Secara Asetilasi Dengan Variasi Konsentrasi Asam Asetat Selama Perendaman. Jurnal Teknologi
Hasil Pertanian, Vol. V, No. 2, Agustus.

Nurud Diniyah, Achmad Subagio, Riri Nur Lutfan Sari, Nugraha Yuwana. 2018. Sifat Fisikokimia, Dan Fungsional Pati Dari Mocaf (Modified Cassava Flour) Varietas Kaspro Dan Cimanggu. Jurnal Penelitian Pascapanen Pertanian Volume 15 No. 2 September 2018 : $80-90$.

Nusa, M. I., Suarti, B. and Alfiah (2012) Pembuatan Tepung Mocaf Melalui Penambahan Starter Dan Lama Fermentasi (Modified Cassava Flour)', Agrium, 17(3), pp. 210217.

Pato, U. et al. (2011) 'Evaluasi Mutu dan Daya Simpan Roti Manis yang Dibuat melalui Substitusi Tepung Terigu dengan Mocaf', Jurnal Sagu, 10(2), pp. 1-8.

Tandrianto, J., Mintoko, D. K. and Gunawan, S. (2014) 'Pengaruh Fermentasi pada Pembuatan Mocaf (Modified Cassava Flour) dengan Menggunakan lactobacillus plantarum terhadap Kandungan Protein', Jurnal Teknik Pomits, 3(2), pp. 143-145.

Seveline. 2018. Pembuatan Tepung Mocaf Dengan Penggunaan Bakteri Asam Laktat Dan Lamanya Perendaman. 